\title{
Erratum to: Why Do Romanian Universities Fail to Internalize Quality Assurance?
}

\author{
Koen Geven, Adina Maricuț, Norbert Sabic, Robert Santa \\ and Oana Sârbu
}

\section{Erratum to:}

Chapter 'Why Do Romanian Universities Fail to Internalize Quality Assurance?', in: A. Curaj et al. (eds.), Higher Education Reforms in Romania, DOI 10.1007/978-3-319-08054-3_3

The sequence of author names was incorrect. The correct sequence is given below. Koen Geven, Adina Maricuț, Norbert Sabic, Robert Santa and Oana Sârbu

Open Access This chapter is distributed under the terms of the Creative Commons Attribution Noncommercial License, which permits any noncommercial use, distribution, and reproduction in any medium, provided the original author(s) and source are credited.

The online version of the original chapter can be found under DOI 10.1007/978-3-319-08054-3_3

K. Geven $(\bowtie)$

European University Institute, Florence, Italy

e-mail: koen.geven@eui.eu

A. Maricuț · N. Sabic

Central European University, Budapest, Hungary

e-mail: maricut_adina@ @eu-budapest.edu

N. Sabic

e-mail: norbert.sabic@gmail.com

R. Santa

Institute of Education, London, England

e-mail: robi.santa@gmail.com

O. Sârbu

ARACIS, Bucharest, Romania

e-mail: oana.sarbu@aracis.ro

(C) The Author(s) 2015

A. Curaj et al. (eds.), Higher Education Reforms in Romania,

DOI 10.1007/978-3-319-08054-3_12 